\title{
Household Debt and Financial Burden in Mexico
}

\author{
Reyna Elizabeth Rodríguez Pérez¹, David Castro Lugo, Luis Sebastian Meneses Cruz² \\ ${ }^{1}$ Faculty of Economics, Autonomous University of Coahuila, Saltillo, Mexico \\ ${ }^{2}$ Center for Socioeconomic Research, Autonomous University of Coahuila, Saltillo, Mexico \\ Email: reynarodriguez@uadec.edu.mx,david.castro@uadec.edu.mx
}

How to cite this paper: Rodríguez Pérez, R. E., Castro Lugo, D., \& Meneses Cruz, L. S. (2020). Household Debt and Financial Burden in Mexico. Modern Economy, 11, 1929-1949.

https://doi.org/10.4236/me.2020.1111129

Received: October 5, 2020

Accepted: November 24, 2020

Published: November 27, 2020

Copyright (c) 2020 by author(s) and Scientific Research Publishing Inc. This work is licensed under the Creative Commons Attribution International License (CC BY 4.0).

http://creativecommons.org/licenses/by/4.0/

\begin{abstract}
The objective of this work is to determine the debt index and identify the financial burden of households in Mexico for 2014 by using the data from ENIGH 2014. The hypothesis to be tested is that during the last few years, households in Mexico are accelerating their dependence on debt to satisfy their consumption and housing needs, which is added to disproportionate interest rates, considerably increases their financial burden, which in many cases slows down or leads to the bankruptcy of the economy of these households. The results indicate that households in the first three deciles are in unsustainable conditions and do not have the financial capacity to meet their expenses and debts, while households in the fourth, fifth and sixth deciles are at financial risk.
\end{abstract}

\section{Keywords}

Debt, Financial Burden, Households, Mexico

\section{Introduction}

Since ancient times, credit has been a common practice in society, since it speeds up the possibility of satisfying needs for food, clothing, shoes, housing, cleaning, health, transportation, education, recreation, etc., which in many cases is not within the reach of families, without them having to resort to options such as credit, although at an extra charge, because of the interest rate they have to pay. During the last few years, households in Mexico have increased their dependence on debt to cover their needs, just to give an example, credit cards. National Council for Financial Inclusion (2017) reports that 26 million contracts were registered at the end of June 2016, followed by personal and payroll loans, with 10.5 and 5.2 million, respectively. These figures are followed by group loans with 
3.4 million, the so-called acquisition of durable consumer goods with 2.7 million and mortgage loans with 1.5 million; automotive loans are in the last place with 0.6 million contracts. Díaz et al. (2019) find that in recent years consumer credit in Mexico grew significantly. Credit cards, which represent $52 \%$ of loans in the country, grew 19\% from 2011 to 2018; while the average debt per card grew $62 \%$. From the above, it can be deduced that the study of indebtedness and the probability of default on financial obligations by households allow us to identify their vulnerabilities to macroeconomic changes that may affect the availability of resources for the payment of debt incurred by households in the financial system. The preparation of this study will allow us to know the financial situation that households in Mexico are going through. Giving answers to the following questions: What is the origin of the debt; What are the variables involved in the debt; What is the disposable income of the households in Mexico; Why is it important to understand the level of income inequality in the households in Mexico related to the debt? What is the direct effect of the credit crunch on debt; What are the causes that drive Mexican households to increase their debt levels; What are the risks faced by households in Mexico with the existing debt levels; Which households are most vulnerable to debt risks? The objective of this work is to determine the debt index and identify the financial burden of households in Mexico in 2014. This research hypothesizes that during the last few years, Mexican households are accelerating their dependence on debt for the satisfaction of their consumption and housing needs, which is added to disproportionate interest rates, considerably increase their financial burden, which in many cases slows down or leads to the bankruptcy of the economy of these households. This work is important because until 2012 the main results of the first Financial Inclusion Survey (ENIF) were released, prepared on the initiative of the National Banking and Securities Commission (CNBV) and the National Institute of Statistics and Geography (INEGI), where for the first time, data on the demand for financial services at the national level has been released and credit is one of the most demanded, so it is interesting to know, what is the debt situation of households in Mexico, as well as their financial burden. To fulfill the objective of this research, data from the National Survey of Income and Expenditures in Homes (ENIGH) 2014 and the Financial Inclusion Survey (ENIF) for the year 2018 are used, and an index of indebtedness in the universe of homes in our country is integrated, highlighting from its origin, to the causes and risks involved in this phenomenon. The results indicate that households in the first three deciles are in unsustainable conditions and do not have the financial capacity to meet their expenses and debts, while households in the fourth, fifth and sixth deciles are at financial risk. The work is divided into four sections. The first one describes several theories and hypotheses about the study of debt. In two, quantitative data on household characteristics are integrated. The third one explains step by step the methodology and the data used. Finally, in the fourth section, the situation of households in Mexico about debt is presented, obtaining the financial burden 
and the debt index. Finally, the conclusions and the consulted bibliography are shown.

\section{Theoretical Analysis and Empirical Evidence}

\subsection{Theoretical Analysis}

The concept of credit is defined as the act by which a person (the creditor) entrusts a tangible asset (money) or intangible asset (lines of credit) to another (the debtor) for a given period, granting an additional payment or premium called interest. Once the term has elapsed, the debtor returns the money to the creditor (INEGI, 2014). Based on this concept some theories have been generated, mainly proposed in the period 1930 to 1997, which are analyzed below.

Keynes (1992), states that the average propensity to consume $(P M e C)$, is a function of disposable income, which is defined as the amount of income remaining after consumption and savings. He explains that the average propensity to consume falls as income increases: $P M e C=C / Y$ and determines that as income increases, consumers save a greater fraction of it, so the average propensity to consume $(P M e C)$ falls. Households with higher incomes consume more. For this model, families with higher disposable income (income plus savings) have a greater propensity to consume.

Although this theory relates to income as a substantial part of consumption, it served as the basis for subsequent studies and postulations of theories and hypotheses, probably leading to the most notorious one: What happens in households whose income is minimal or nil, the answer to this question can be obtained in the following theory postulated by Fisher (1930), where the intertemporal relationship is analyzed.

For Fisher (1930), in his theory of the intertemporal relationship, how much more the consumer earns in each moment is irrelevant, since he can save or get into debt between periods. This theoretical evidence puts for the first time great relevance to the issue of debt in the daily performance of human life and will be the pillar together with the study of the Keynesian theory on the issue of consumption.

Fisher (1930) mentions that the consumer is a saver, the increase in his income benefits him, which tends to accelerate his consumption in the present and future, therefore, if the increase in his income raises the opportunity cost of present consumption, it tends to reduce his present and future consumption.

In both situations, according to Fisher (1930), the income effect and the substitution effect increase future consumption $(C 2)$. The behavior of present consumption $(C 1)$ as it increases or decreases will depend on the relative size of the income and substitution effects. To exemplify his theory he assumes that: the consumer is forward-looking and chooses present and future consumption that maximizes his satisfaction throughout his life, the consumer's choice is subject to intertemporal budget constraint, a measure of the total resources available for present (1) and future consumption (2). Where: 
$Y 1, Y 2=$ rent in the periods 1,2

$C 1, C 2=$ consumption in the periods 1,2

In period 1 (present), savings $(S)$, can be given by subtracting present consumption $(C 1)$, from present income $(Y 1), S=Y 1-C 1$; if savings are less than zero the consumer is in debt in the present period (1), $S<0=\operatorname{debt~(~} r=$ income).

In period 2, it manifests the intertemporal budgetary restriction and determines that:

$$
C 2=Y 2(1+r) S \text { or } C 2=Y 2+(1+r)(y 1-C 1)
$$

from where it formulates to $(1+r) C 1+C 2=Y 2+(1+r) Y 1$ is divided by $(1+r)$, to obtain.

The present value of consumption in both periods is equal to the present value of income in both periods.

$$
C 1+C 2 / 1+r=Y 1+Y 2 / 1+r
$$

Fisher (1930), in his theory, determines the marginal substitution ratio (MSR), which is the amount of consumption in period two $C 2$, that the consumer will be willing to substitute in exchange for a unit of consumption one $C 1$, and mentions that an increase in his income in period one $(Y 1)$ or period two $Y 2$, no matter in which period the consumption $C 1$ y $C 2$ will increase.

Unlike Keynes' theory, where current consumption depends only on present income, Fisher determines in his theory that immediate consumption depends on the present value of income throughout life. The more you earn in each period is irrelevant, since the consumer can save or get into debt, between periods. Give rise to the theory of the life cycle.

Later on, unlike Fisher's intertemporal theory, Modigliani (1970) established his life cycle theory where

$W=$ initial wealth, $Y=$ annual income until retirement (constant),

$R=$ number of years until retirement, $T=$ life span in years

It is important to note that this theory states that

$$
\text { vital resources }=W+R Y
$$

To achieve uniformity in consumption, the consumer divides his resources equally throughout his life:

$$
C=(W+R Y) T \text { or } C=\propto W+\beta Y
$$

where:

$\propto=1 / T$ is the marginal propensity to consume from wealth.

$\beta=R / T$ is the marginal propensity to consume from income.

The function of consumption in the life cycle implies

$P M e C=C / Y=\propto(W / Y) \beta$.

It states that: income varies more than wealth, so high-income households should have a lower QPI than low-income households. Over time, wealth and aggregate income grow in unison, causing the HIPC to remain stable. 
In this model, it is important to highlight that it maintains the assumptions of zero interest rates, and consumption remains constant in an optimal way, so the integration of debt would vary considerably and its behavior would return to that postulated by Fisher.

Friedman (1957), postulates his theory of the Hypothesis of Permanent Income.

The hypothesis of permanent income implies: $P M e C=C / Y=\alpha Y P / Y$

If high-income households have higher incomes than low-income households, the HIPC is lower in high-income households. In the long term, variations in income are mainly due to changes in permanent income, which implies a stable HIPC.

$$
Y=Y P+Y T
$$

where: $Y=$ Current income, $Y P=$ Permanent income (average income, what people expect to persist in the future).

The consumption function of the permanent income hypothesis is:

$$
C=\alpha Y P
$$

where: $\alpha=$ The proportion of permanent income that people consume per year.

If we relate the permanent income hypothesis to the life cycle one, in both, people try to balance their consumption, when faced with changes in their present income. In the former, current income is subject to transitory and random fluctuations. In the life cycle hypothesis, the current income varies systematically as people evolve their life cycle, throughout their existence. Again put savings or debt as a tool to balance their consumption. As mentioned by Fisher's theory, consumers use savings and debt to balance their consumption in response to transient changes in their income.

Later, Hall (1978), postulates the Random Walk Hypothesis, based on Fisher's model and the hypothesis of permanent income. As Mankiw (2007) describes in his analysis of consumption theories, this closes a cycle from 1930 to 1978, where consumers were analyzed maintaining rational expectations, and especially this theory where: a change in income or wealth that was predicted has already been contemplated as information in the expectations of permanent income, so it does not modify consumption, only the unforeseen changes in income or wealth, which alter the expected permanent income, will modify consumption.

Of the most current theories, we find the one described by Laibson \& Harris (2001), who develops the psychology of immediate gratification, in which he considers the psychology of consumers, and explains why people do not save as much as a utility-maximizing agent would throughout their lives. This latter theory of consumption could explain why the emotional behavior of consumers or immediate gratification can or should be considered. To demonstrate consumer psychology, he uses human behavior survey tools to test his hypothesis such as the following: it consists of two questions of inconsistency over time: 1) would you prefer a) one candy today, b) two candies tomorrow? 2) would you 
prefer a) one candy in 100 days or b) two candies in 101 days?

In this question, the results showed that most people answer (a) question 1 and (b) question 2. Therefore, in question 2, the answer (b) is usual, but in 100 days, when the same person is faced with question 1, the influence of immediate gratification may induce him/her to change his/her answer. Emotional behavior becomes another important factor in analyzing debt.

Having outlined the different theories and models that explain the behavior of individuals when faced with consumption and debt acquisition, we proceed to review the different empirical studies that attempt to measure this phenomenon.

\subsection{Empirical Evidence}

This measurement and others are deliberate, using specifications that anticipate your paper as one part of the entire journals, and not as an independent document. Please do not revise any of the current designations. In this part, various empirical works on the subject are analyzed. Fuenzalida \& Ruiz Tagle (2009), comments on the financial risk in households for Chile, emphasizing the scarce information that allows determining the financial indebtedness of individuals at the household level, and until 2007 through the household financial survey (EFH), which facilitates the study of this phenomenon, and mentioning countries such as Sweden and Norway that are leaders in the field.

Continuing with Fuenzalida \& Ruiz Tagle (2009), in their analysis of financial risk they highlight the macroeconomic comparison, as a measurement that could be within the normal parameters with other countries, however, in the microeconomic field the results can be alarming and therefore they applaud the effort of financial inclusion in the homes achieved in 2007, which allowed Chile to make a more precise study of the debt, they argue that countries like Sweden and Norway, show negative margins, by including liquid and illiquid assets as collateral for the debts. The measurement is calculated by the Chilean Central Bank and is defined as the financial margin for the household:

$$
M h=Y h-C F h-G h
$$

where: $Y h=$ household income, $C F h=$ household financial burden, $G h=$ total household expenditure.

Following Fuenzalida \& Ruiz Tagle (2009), it adds to its study model the Kaplan-Meier estimator (1958), and Cox's semiparametric model (Cox, 1972). Add variables such as the probability of unemployment among others. Hence the achievement of results with correlation estimators, which allows timely planning on the issue of a financial burden on households. It is important to emphasize the research of the Chilean case since its study allows it to include variables of the probability of financial risk, and tendencies based on employment, with Cox's model, starting from the probability that by being employed one maintains a constant income which allows one to solve one's spending needs, up to the indicator based on the educational level about income using the Kaplan-Meier model.

On the other hand, in Colombia since 2011, the analysis is being undertaken 
through the implementation of the financial education and financial burden survey (Iefic). Derived from the study provided by the Department of National Administration of Statistics (DANE), and the Bank of the Republic, in its study approximates the degree of over-indebtedness of a household from the indicator of financial burden, monitoring the state of credit risk and whose main feature divides it between debt for consumption and debt for housing, and it is noteworthy that this study whose background refers to the Italian Bank, as an initiator in the realization of household budget survey information, followed by countries like the United States, which since 1983 applies the survey of the families of the consumers of the Federal Reserve, mentioning the design of the financial survey of the families applied since 2003 in Spain until 2007 in Latin America with the incursion of this type of surveys in the Chilean countryside.

The population characteristics and financial policies are different, however, it is clear that the search for development leads to more efficient monitoring of the debt in the homes in the previous study.

In a study for Mexico, López (2012), estimates that the income destined for debt payment in Mexican households amounted to 1700 pesos per month. Approximately 35 percent of the family income was committed to this item, highlighting that the sum of the internal debt in the homes corresponded to 14.3 percent of the gross domestic product (GDP). A very respectable approximation of the national average, however, when analyzing the financial burden per household the favorable comparison with the GDP, would be unacceptable for our financial system, since there is the probability that a large number of households are surviving by transferring the expense of living a family bankruptcy due to debt.

Recently, Díaz et al. (2019) analyzed the determinants of household over-indebtedness in Mexico (representing expenditures of over $40 \%$ of their income), and offered explanations in terms of the political-economic factors that favor such a configuration. In principle, the proposed analysis is short term and uses data from the National Banking and Securities Commission (CNBV, 2015) to analyze, on the supply side, the increase in credit and the probabilities of default. And, on the demand side, it uses the ENIGH, which allows the analysis of the uses of credit, the level, and factors that determine the over-indebtedness of households. The methodology of artificial neural networks (ANN) allows the analysis of both linear and non-linear relationships. With the review of the empirical literature, it can be deduced that the origin of the debt is in the conception of consumption, and its base around the disposable income of the households, which would be the sum of their savings plus their income, which in the case of being weak they use the debt to guarantee their needs, increasing their expectations. Developed countries have a clear indicator of financial risk in their homes, and even as in the Spanish case in 2007, and U.S.A. 2008, they did not avoid submerging themselves in great economic crises, if it has been key to find the mechanisms of exit to it, with the correct identification of the problem that caused them, in Mexico as found by López (2012) and Díaz et al. (2019), the 
country faces different financial characteristics than those countries experienced in monitoring financial risk, and the largest of these is the construction of a base per household, to assess risks and implement economic strengthening measures per household, since as mentioned by Fuenzalida \& Ruiz Tagle (2009), in the case of Chile, macro-economically the comparison with other nations can be satisfactory, but by taking it to each of the households, this comparison will approximate a real indicator.

\section{Data and Methodology}

The objective of this work is the construction of the index of indebtedness and financial burden in the households to 2014, this around the study of the distribution of the population characteristics in the selected period, the samples taken is of 31 million 548 thousand 045 households.

The variables related to debt for the study are derived from the level of income and expenditure and the percentage that each household allocates to the payment of each concept or type of debt, with the limitations established in the previous sections. It is important to clarify that the Bank of Mexico requests the INEGI, through its household surveys, to apply the first financial inclusion survey, and this will be published in 2018, with very important results, but for the creation of a debt history they are insufficient for comparison and only the most relevant debt aspects are taken as a reference.

The official information published about the debt, in the selected period of analysis, by related organizations in the financial sector such as: Banco Nacional de México (BANXICO), Comisión Nacional Bancaria y de Valores (CNBV), and the Comisión Nacional en la defensa de los Usuarios y Servicios Financieros en México (CONDUSEF) is taken.

The methodology used is a descriptive analysis, giving it a theoretical basis, towards the qualitative verification of hard data that puts the problem described in the hypothesis. Due to the diversity of concepts to be considered to correlate expectations such as the interest rate in the contracting of debt per household and other variables such as inflation, age, at the household level, this research is limited to determining the financial burden for the acquisition of debt, and the debt index, in the households of Mexico.

The following is a description of how exposure to the financial burden of debt acquisition in Mexican households is constructed:

First, the quarterly available income per household in 2014 is obtained: The current income is divided into its components: income from work, property income, transfers, estimated rent, other current income.

The current income is separated into its components to interpret the financial burden on the household in 2014. The current income is classified in deciles for study purposes, with I being the lowest income and $\mathrm{X}$ being the highest. From this first analysis it is clear:

We calculate the real income in the homes of Mexico in the year 2014, with 
data from the National Survey of Income and Expenditures in Homes (ENIGH). The ENIGH defines this as the estimated value of the rent that the household would have to pay in the market for the housing of the same size, quality, and location. This estimate is made by the informant him/herself based on his/her appreciation of the market value of the rent of his/her dwelling; therefore, since it is an estimate and not actual income, it is removed from the sample.

Separation is made between real income and household spending in Mexico in the year 2014.

The available income per quarter per household in Mexico in 2014: Available income is obtained and then compared with the burden of debt payment in the households by separating it and calculating the financial burden against available income.

A relationship is made between available income and the possibilities of acquiring debt in Mexican households: A projection of the propensity for debt is made with the characteristics of the households.

The interest rate in Mexico in the year 2014 and its relationship to debt is analyzed.

The financial burden of debt payment in Mexican households per quarter in the year 2014 is determined: 1) The financial burden of paying for housing. 2) The financial burden for the payment of credit cards. 3) The financial burden for debt payment.

It is obtained: $C f t=c f A+c f b+a f c$

To find out what the financial burden of debt payment is, it represents income and expense:

$C f t$ about actual income and $C f t$ about the total expense

The real average income $M i$, and the total average expenditure $M g t$ are taken, and the charge that represents in each one of them the total financial burden for debt payment is determined: $C f t$, applied in the deciles I, II, III, IV, V, VI, VII, VIII, IX and X. Analyzing and exposing its result.

The index of indebtedness is determined, in the households of Mexico in the year 2014. Based on real income, expenditure, and financial burden, Separate from average total household expenditure $(M g t)$, the amount allocated to debt payment $(C f t)$.

$$
M g t-C f t
$$

Applied in the deciles I, II, III, IV, V, VI, VII, VIII, IX, and X. The result is divided by the total household income $(Y T h)$,

$$
\text { Ie }=M g t-C f t / I r
$$

The following are the results.

\section{Result}

In this section, the debt index and the financial burden per household are constructed (all data are calculated as of the third quarter of 2014). It begins with: 1) 
the composition of variables, based on characteristics and classification, 2) separation of current income, 3) calculation of real income, 4) separation of real income from expenditure.

In Table 1, characterization and classification of Mexican households are made, taking the current quarterly income received as of 2014, divided into 10 deciles. The results indicate that the average per household in decile I am 5687.81 , in decile II with an average income of 9680.47, and decile III with an average income of $13,040.42$, decile IV with a median income of $16,712.09$, decile $\mathrm{V}$ with a median income of 20,590.56, decile VI with a median income of $25,310.53$, decile VII with a median income of $31,501.39$, decile VIII with a median income of 40,462.48, decile IX with a median income of 55,409.17, and decile $\mathrm{X}$ with a median income of $122,717.7$.

In Table 2, the current income is separated to determine the financial burden per household, which is calculated on the income from work (sum of income from work, business, and other jobs), equivalent to 66.53 percent of the average, and the income from property (income that household members receive from the possession of financial or tangible assets that they have made available to other institutional units), equivalent on average to 1.9 percent of current income, income equivalent to transfers (retirement, scholarships, donations, remittances, government benefits, transfer from another household, and transfer from non-governmental institutions), equals on average 22.37 percent of current income, estimated rent (estimated value of the rent that the household would have to pay in the market for the housing of the same size, quality, and location) equals 15.11 percent of current income, and the average of other current income is 0.14 percent of current income.

In Table 3, the real income is calculated by separating the estimated income

Table 1. Current income by deciles of households in Mexico 2014.

\begin{tabular}{ccccccc}
\hline Decil & observations & Proportion of homes & Mean income & Std dev & Min & Max \\
\hline I & $2,479,559$ & 7.86 & 5687.812 & 1537.878 & 146.73 & 7909.33 \\
II & $2,502,176$ & 7.93 & 9680.471 & 997.6614 & 7912.97 & $11,322.44$ \\
III & $2,730,289$ & 8.65 & $13,040.42$ & 968.5712 & $11,323.58$ & $14,785.6$ \\
IV & $3,104,984$ & 9.84 & $16,712.09$ & 1106.791 & $14,787.11$ & $18,588.32$ \\
V & $3,068,943$ & 9.72 & $20,590.56$ & 1161.71 & $18,590.14$ & $22,773.07$ \\
VI & $3,320,062$ & 10.52 & $25,310.53$ & 1486.606 & $22,789.57$ & $27,984.41$ \\
VII & $3,479,406$ & 11.02 & $31,501.39$ & 2154.845 & $27,988.03$ & $35,378.82$ \\
VIII & $3,433,210$ & 10.88 & $40,462.48$ & 3107.088 & $35,381.02$ & $46,084.32$ \\
IX & $3,497,818$ & 11.08 & $55,409.17$ & 6073.75 & $46,090.6$ & $67,515.66$ \\
X & $3,942,932$ & 12.49 & $122,717.7$ & $80,839.83$ & $67,597.77$ & $792,894.4$ \\
Total & $31,559,379$ & 100 & $34,111.2623$ & & & \\
\hline
\end{tabular}

Own elaboration based on microdata from the national survey of household income and expenditure in Mexico 2014. 
Table 2. Proportional breakdown of current household income in Mexico 2014.

\begin{tabular}{|c|c|c|c|c|c|}
\hline $\begin{array}{l}\text { Mean income } \\
\text { current per decile }\end{array}$ & Work & $\begin{array}{l}\text { Rentals } \\
\text { to the property }\end{array}$ & Transfers & $\begin{array}{l}\text { Estimate } \\
\text { for rent }\end{array}$ & Others \\
\hline 5687.812 & 36.24 & 1.02 & 38.19 & 24.3 & 0.25 \\
\hline 9680.471 & 46.65 & 0.49 & 33.01 & 19.38 & 0.47 \\
\hline $13,040.42$ & 55.73 & 0.86 & 26.35 & 16.96 & 0.1 \\
\hline $16,712.09$ & 57.43 & 1.05 & 25.72 & 15.61 & 0.19 \\
\hline $20,590.56$ & 66.35 & 0.91 & 19.13 & 13.57 & 0.04 \\
\hline $25,310.53$ & 65.7 & 1.77 & 18.3 & 14.2 & 0.03 \\
\hline $31,501.39$ & 67.26 & 0.99 & 18.37 & 13.24 & 0.15 \\
\hline $40,462.48$ & 71.42 & 1.83 & 13.84 & 12.9 & 0.01 \\
\hline $55,409.17$ & 71.51 & 2.1 & 15.5 & 10.84 & 0.05 \\
\hline $122,717.7$ & 66.53 & 7.94 & 15.28 & 10.09 & 0.17 \\
\hline $34,111.2623$ & 60.48 & 1.9 & 22.37 & 15.11 & 0.14 \\
\hline
\end{tabular}

Own elaboration based on microdata from the national survey of household income and expenditure in Mexico 2014.

Table 3. Current income minus estimated household rent in Mexico 2014.

\begin{tabular}{cccccccc}
\hline Decil & Obs & $\begin{array}{c}\text { Mean income } \\
\text { before rental } \\
\text { estimate }\end{array}$ & $\begin{array}{c}\text { Mean income } \\
\text { after rental } \\
\text { estimate }\end{array}$ & $\begin{array}{c}\text { Difference } \\
\%\end{array}$ & Std dev & Min & Max \\
\hline I & $2,553,577$ & 5687.812 & 4057.321 & -28.67 & 1357.109 & 48.91 & 6089.66 \\
II & $2,590,424$ & 9680.471 & 7748.94 & -19.95 & 911.714 & 6094.55 & 9254.33 \\
III & $2,857,160$ & $13,040.42$ & $10,858.7$ & -16.73 & 906.838 & 9254.83 & $12,377.18$ \\
IV & $3,092,569$ & $16,712.09$ & $14,261.18$ & -14.67 & 1042.555 & $12,378.43$ & $16,012.35$ \\
V & $2,999,296$ & $20,590.56$ & $17,883.08$ & -13.15 & 1024.359 & $16,012.46$ & $19,711.94$ \\
VI & $3,336,448$ & $25,310.53$ & $21,998.83$ & -13.08 & 1412.653 & $19,714.95$ & $24,590.16$ \\
VII & $3,317,118$ & $31,501.39$ & $27,633.17$ & -12.28 & 1838.885 & $24,607.67$ & $31,049.95$ \\
VIII & $3,453,768$ & $40,462.48$ & $35,819.39$ & -11.48 & 3015.828 & $31,057.76$ & $41,331.51$ \\
IX & $3,505,344$ & $55,409.17$ & $49,902.04$ & -9.94 & 5320.737 & $41,380.42$ & $60,786.85$ \\
X & $3,842,341$ & $122,717.7$ & $112,260.5$ & -8.52 & 78054.07 & $60,790.99$ & $792,894.4$ \\
Total & $31,548,045$ & & & & & &
\end{tabular}

Own elaboration based on microdata from the national survey of household income and expenditure in Mexico 2014

by rent, in decile I the difference is -28.67 percent, remaining with an income of 4057.32, decile II decreases by -19.95 percent with an income of 7748.94 . Decile III decreases by -16.73 percent with a minimum of 9254.83 to $12,377.18$. Decile IV decreases its income by -14.67 percent with a minimum of $12,378.43$ and a maximum of $16,012.35$. Decile $V$ decreases by -13.15 percent with a minimum of 16,012.46 and a maximum of 19,711.94. Decile VI decreases by 13.08 percent with a minimum of $19,714.95$ and a maximum of $24,590.16$. Decile VII decreases 
its income by up to -12.28 percent with a minimum of $24,607.67$ and a maximum of $31,049.95$. Decile VIII decreases its income by -11.48 percent with a minimum of $31,057.76$, and a maximum of $41,331.51$. Decile IX decreases its income by -9.94 percent with a minimum of $41,380.42$ and a maximum of $60,786.85$, and Decile $\mathrm{X}$ decreases its income by -8.52 with a minimum of $60,790.99$ and a maximum of 792,894.4.

Table 4 shows the total quarterly current expenditure of households in Mexico, which is made up of monetary expenditure (food, clothing, housing, cleaning, health, transportation and communication, education, personal expenses, and transfers), and non-monetary expenditure (in-kind expenditures and in-kind transfers): Decile I, spending a total of 8249.1, Decile II, 10,035.43, Decile III, 12,546.26, Decile IV, 14,638.9, Decile V, 16,806.54, Decile VI, 20,403.52, Decile VII, 23,068.89, Decile VIII, 28,395.59, Decile IX, 37,877.78, and Decile X, $70,752.29$.

The data in Table 5, allow us to know how the total expenditure is integrated. From the result shown in the table above, it is worth noting that current monetary spending on food, from decile I to X, corresponding to $51.36,50.5,46.94$, $46.17,44.79,40.43,38.99,36.27,31.11$ and only 23.72 percent, housing, in the same classification as $10.07,9.76,10.23,10.72,10.02,9.83,9.40,8.60$, to 7.84 successively, and the expenses for transportation, represent 9.61, 11.61, 12.96, $14.23,14.88,16.87,18.28,18.92,21.75$, until 20.34 in this item the households with higher income spent more.

In Table 6, available income is calculated by subtracting total expenditures. The results indicate that by 2014 , households in Mexico that were in deciles I, II, III, IV with 35.16 percent cumulative of total households, and average real income up to $14,261.18$ per quarter with $-103.31,-29.51,-15.54$ and -2.65 percent respectively of available income, are in total dependence on income transfer

Table 4. Total disaggregated current expenditure, including non-monetary current expenditure, in Mexican households in 2014.

\begin{tabular}{cccc}
\hline Decil & Total current expenditure & Money Runner Gasto & Gasto corriente no monetary \\
\hline I & 8249.1 & 90.72 & 9.28 \\
II & $10,035.53$ & 93.14 & 6.86 \\
III & $12,546.26$ & 93.71 & 6.29 \\
IV & $14,638.9$ & 94.19 & 5.81 \\
V & $16,806.54$ & 95.75 & 4.25 \\
VI & $20,403.52$ & 95.89 & 4.11 \\
VII & $23,068.89$ & 95.84 & 4.16 \\
VIII & $28,395.59$ & 97.33 & 2.67 \\
IX & $37,877.78$ & 97.39 & 2.61 \\
X & $70,752.29$ & 98.38 & 1.62 \\
\hline
\end{tabular}

Own elaboration with ENIGH 2014 data. 
Table 5. Percentage of total current expenditure, of its components, in Mexican households in 2014.

\begin{tabular}{cccccccccccc}
\hline Decil & Money Runner Gasto & Foods & Clothing & Housing & Cleaning & Health & Transportation & Education & Personal & Transfer \\
\hline I & 7483.44 & 51.36 & 4.05 & 10.07 & 5.82 & 1.82 & 9.61 & 5.36 & 6.44 & 5.43 \\
II & 9346.67 & 50.5 & 4.25 & 9.76 & 6.21 & 3.22 & 11.61 & 5.88 & 7.27 & 1.26 \\
III & $11,756.94$ & 46.94 & 4.63 & 10.23 & 5.58 & 2.02 & 12.96 & 8.01 & 7.64 & 1.95 \\
IV & $13,788.03$ & 46.17 & 4.63 & 10.72 & 5.12 & 1.64 & 14.23 & 9.19 & 6.97 & 1.30 \\
V & $16,092.4$ & 44.79 & 5.11 & 10.02 & 5.45 & 2.35 & 14.88 & 8.51 & 7.18 & 1.68 \\
VI & $19,565.16$ & 40.43 & 4.87 & 9.83 & 5.17 & 3.61 & 16.87 & 9.55 & 6.85 & 2.80 \\
VII & $22,110.19$ & 38.99 & 4.76 & 9.40 & 5.00 & 2.10 & 18.28 & 11.24 & 7.67 & 2.52 \\
VIII & $27,636.11$ & 36.27 & 5.31 & 8.67 & 5.34 & 2.45 & 18.92 & 13.5 & 7.07 & 2.45 \\
IX & $36,887.99$ & 31.11 & 5.47 & 8.60 & 5.58 & 1.92 & 21.75 & 13.77 & 7.77 & 4.01 \\
X & $69,607.92$ & 23.72 & 5.31 & 7.84 & 7.32 & 2.80 & 20.34 & 19.26 & 7.34 & 6.05 \\
\hline
\end{tabular}

Own elaboration based on microdata from the national survey of household income and expenditure in Mexico 2014.

Table 6. Household disposable income in Mexico in 2014.

\begin{tabular}{|c|c|c|c|c|c|c|c|}
\hline Decil & Obs & Hogares \% & Acumulativo \% & Media del ingreso real & Media del gasto total & $\begin{array}{l}\text { Media del ingreso } \\
\text { disponible }\end{array}$ & ${ }^{\star}$ Ingreso disponible $\%$ \\
\hline I & $2,553,577$ & 8.09 & 8.09 & 4057.321 & 8249.1 & -4191.779 & -103.31 \\
\hline II & $2,590,424$ & 8.21 & 16.31 & 7748.94 & $10,035.53$ & -2286.59 & -29.51 \\
\hline III & $2,857,160$ & 9.06 & 25.36 & $10,858.7$ & $12,546.26$ & -1687.56 & -15.54 \\
\hline IV & $3,092,569$ & 9.80 & 35.16 & $14,261.18$ & $14,638.9$ & -377.72 & -2.65 \\
\hline $\mathrm{V}$ & $2,999,296$ & 9.51 & 44.67 & $17,883.08$ & $16,806.54$ & 1076.54 & 6.02 \\
\hline VI & $3,336,448$ & 10.58 & 55.25 & $21,998.83$ & $20,403.52$ & 1595.31 & 7.25 \\
\hline VII & $3,317,118$ & 10.51 & 65.76 & $27,633.17$ & $23,068.89$ & 4564.28 & 16.52 \\
\hline VIII & $3,453,768$ & 10.95 & 76.71 & $35,819.39$ & $28,395.59$ & 7423.8 & 20.73 \\
\hline IX & $3,505,344$ & 11.11 & 87.82 & $49,902.04$ & $37,877.78$ & $12,024.26$ & 24.10 \\
\hline $\mathrm{X}$ & $3,842,341$ & 12.18 & 100 & $112,260.5$ & $70,752.29$ & $41,508.21$ & 36.97 \\
\hline Total & $31,548,045$ & 100 & & & & & \\
\hline
\end{tabular}

Own elaboration with data of the ENIGH in the year 2014. ${ }^{*}$ Unavailable (available income), is the representation in the percentage of the value that corresponds to the available income.

for their subsistence. These deciles would be the most vulnerable. Decile V would have a disposable income of 1076.54, 6.02 percent of its real income; Decile VI, with a disposable income of 1595.31 , representing 7.25 percent of its real income; and Decile VII, with a disposable income of 4564.28, representing 16 percent. 52 of their real income, Decile VIII with an available income of 7423.8 representing 20.73 percent of their real income, Decile IX with an available income of 12,024.26 representing 24.10 percent of their real income, and Decile X with an available income of $41,508.21$ representing 36.97 percent of their real income.

The relationship between disposable income and the possibility of acquiring 
debt is shown in Table 7. The sample of homes corresponds to 31 million 548 thousand 045 , according to the table above, 35.16 percent of homes in our country is in total bankruptcy with a negative disposable income, corresponding to deciles I, II, III, IV. deciles V and VI, represent 20.09 percent, slightly in a positive situation with 6.2 and 7.25 percent respectively, 1076.54 and 1595.31 pesos per quarter, and deciles VII, IX, and IX, which represent 32.57 percent of the population with available income, range from 4564.28, 7423.8, and 12,024.26 pesos in the quarter, and only 12.18 percent with $41,508.21$ average available income representing 36.97 percent of their real average income.

In Figure 1, available income is analyzed and the possibility of acquiring debt, or savings, and investment is weighted. The results indicate that the households in decile $\mathrm{X}$ have a greater possibility of disposable income and better conditions for negotiating some debt or deciding to save or invest, with 54 percent of possibilities in favor, but from there they drop considerably to 16 percent, and 10 percent of possibilities in deciles IX and VIII respectively and deciles VII, VI, V, IV. With fewer possibilities with 6,2,1 and 1 percent successively and deciles III, II, and I, in a true situation of survival with $-2,-3$ and -5 percent possibilities, it is important to clarify that the lower the disposable income the greater the propensity towards debt since it is an alternative to satisfy some need.

The specific objective of this work is to get to know the financial burden, therefore the financial expenditures that we saw in the components of the expense are determined, and from there the corresponding ones to debt payment are separated, being: 1 ) installment paid by housing: installment paid by the own housing and is paying, 2) payment by credit card: payment by credit card to the bank or commercial house. And finally, 3) payment of debts: payment of debts of the members of the household to the company where they work and/or to

Table 7. The financial burden of debt payment for housing, in Mexican households in 2014.

\begin{tabular}{cccccc}
\hline Decil & \multirow{2}{*}{ Obs } & Mean & Std. Dev. & Min. & Max. \\
\hline I & 5172 & 1451.61 & 0 & 1451.61 & 1451.61 \\
II & 3130 & 3000.00 & 0 & 3000 & 3000 \\
III & 59,519 & 5530.078 & 5149.856 & 1050 & $21,774.19$ \\
IV & 49,143 & 3337.848 & 982.0465 & 580.64 & 4645.16 \\
V & 46,597 & 2865.697 & 1399.81 & 717.09 & 5806.45 \\
VI & 135,190 & 3618.707 & 1886.82 & 725.8 & $10,161.29$ \\
VII & 134,682 & 4630.09 & 2533.955 & 1542 & $13,935.48$ \\
VIII & 218,722 & 5746.119 & 5601.704 & 1741.93 & $39,193.54$ \\
IX & 246,706 & 6568.024 & 3376.735 & 1800 & 21,900 \\
X & 390,375 & $13,935.02$ & $12,676.35$ & 580.64 & 69,000 \\
\hline
\end{tabular}

Own elaboration based on ENIGH 2014 data. ${ }^{*}$ Those whose value is equal to zero are discarded from the observations. ${ }^{*}$ The deciles are determined in the same way as with the income of $\mathrm{I}$, those with the lowest income obtain up to $\mathrm{X}$, those with the highest income. 


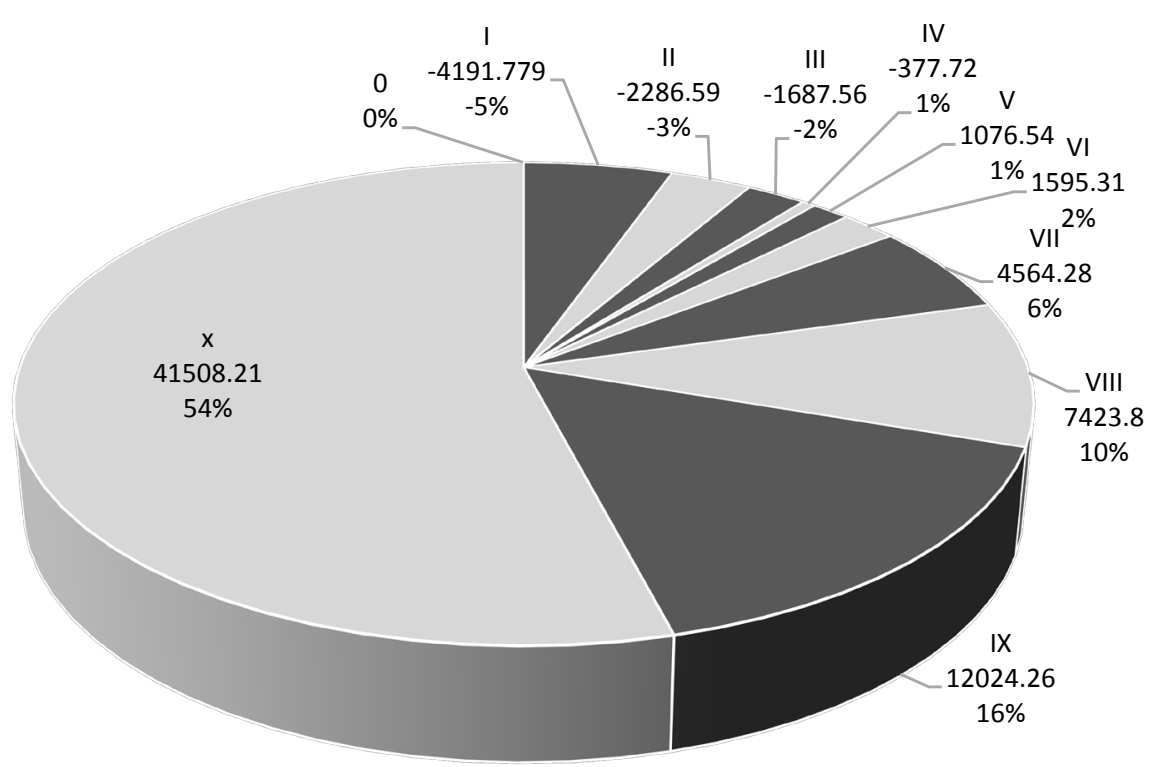

Figure 1. Projection of available income, towards the possibility of contracting debt. 2014. Own elaboration based on analysis of available income and projection of the possibility of contracting debt, weighing the samples in possibilities of debt acquisition, in the year 2014 .

other persons or institutions, which we will analyze individually to determine the financial burden on the households.

The financial burden in the year 2014, for the concept of housing payment, for the results excludes households from deciles I, II, III. Due to the precariousness of their situation according to the analysis of available income, the standard deviations obtained in the results are explained. The households in decile IV range from a minimum payment of 580.64 to a maximum of 4645.16 per quarter, with an average of 3337.809 to a maximum of 5806.45 and an average of 2865.6 those of decile VI, with a minimum payment of 725.8 to a maximum of $10,161.29$, and an average of 3618.7 , those of decile VII, with a minimum payment of 1545 , to a maximum of $13,935.48$, with an average of 4630.09 , those in decile VIII, with a minimum payment of 1542 and a maximum of 13,935.48 and an average of 5746.09 , those in decile IX, with a minimum payment of 1800 and a maximum of 21,900 and an average of 65,68.02 and finally those in decile $\mathrm{X}$, with a minimum payment of 580.64 to a maximum of 69,000 and an average of $13,935.02$.

The above results show a clear condition of debt payment for housing in the middle-income households from the fourth to the ninth deciles, opening a huge gap with the deciles of disposable income greater than $\mathrm{X}$, and with no debt capacity for housing in the first, second and third deciles.

In Table 8, the financial burden for card payment in Mexican households in 2014 per quarter behaved as follows: decile I, with a minimum payment of 748.36 and a maximum of $11,803.27$ with an average of 2084.94 , decile II with a minimum payment of 24.59 , to a maximum of 8852.45 , and an average of 1502.15 , 
Table 8. The financial burden of credit card payments, by a quarter in Mexican households in 2014.

\begin{tabular}{cccccc}
\hline Decil & ${ }^{*}$ Obs & Mean & Std. Dev. & Min. & Max. \\
\hline I & 10,228 & 2084.946 & 2873.296 & 748.36 & $11,803.27$ \\
II & 40,679 & 1502.155 & 2515.923 & 24.59 & 8852.45 \\
III & 75,047 & 3731.981 & 10658.3 & 110.05 & $44,021.73$ \\
IV & 79,619 & 1997.37 & 2907.746 & 59.01 & $12,924.78$ \\
V & 112,225 & 2483.114 & 3827.807 & 245.9 & $17,213.11$ \\
VI & 137,362 & 2708.891 & 3909.38 & 78.68 & $14,673.91$ \\
VII & 259,912 & 2073.007 & 2646.286 & 98.36 & $18,688.52$ \\
VIII & 466,722 & 3443.812 & 3754.135 & 73.77 & $27,049.18$ \\
IX & 739,203 & 5068.8 & 6100.902 & 9.83 & $29,347.82$ \\
X & 153,0341 & $13,315.89$ & $19,140.78$ & 342.39 & $117,391.3$ \\
\hline
\end{tabular}

Own elaboration based on ENIGH 2014 data. ${ }^{*}$ Those whose value is equal to zero are discarded from the observations. ${ }^{*}$ The deciles are determined in the same way as with the income of $\mathrm{I}$, those with the lowest income obtain up to $\mathrm{X}$, those with the highest income.

decile III, with a minimum payment of 110.05 , and a maximum of $44,021.73$, with an average of 3731.98 , decile IV, payment from a minimum of 59.01 to a maximum of $12,924.78$ and an average of 1997.37, decile V, payment from a minimum of 245.9 and a maximum of $17,213.11$, with an average of 2483.11 , decile VI, made from a minimum payment of 78.68 to a maximum of $14,673.91$, with an average of 2708.89 , households in decile VII, with a minimum payment of 98.36 and a maximum of $18,688.52$, with an average of 2073.007 , households in decile VIII, with a minimum payment of 73.77 , to a maximum of $27,049.18$ with an average of 3443.812 , those in decile IX with a minimum payment of 9.83 to a maximum of $29,347.82$, with an average payment of 5068.8 , and finally those in decile $\mathrm{X}$ with a minimum payment of 342.39 to a maximum of $117,391.3$ with an average payment of $13,315.89$.

From the above, we can highlight that even with a minimal possibility in the lower-income deciles, and this type of credit is present, contrasting sharply with the access of households with higher available income.

In Table 9, the concept of debt in this category represents the payment of debts of the members of the household to the company where they work and/or to other persons or institutions, whose behavior in 2014 in the quarter was as follows: households in decile I, paid a minimum of 24.59 to a maximum of 2230.43 with an average of 647.02 , those in decile II, with a minimum of 98.36 to a maximum of $17,804.34$, those in decile III, with a minimum of 39.34 to a maximum of $12,634.23$, those in decile IV, with a minimum payment of 35.4 to a maximum of 9782.6 , with an average of 1811.38 , those in decile $\mathrm{V}$, with a minimum payment of 29.34 and a maximum of 7160.86 , households in decile VI, with a minimum payment of 185.86 and a maximum of $23,478.26$ and an average payment of 2524.73 , those in decile VII, with a minimum payment of 49.18 
Table 9. The financial burden of debt payment in Mexican households in 2014.

\begin{tabular}{cccccc}
\hline decil & Obs & Mean & Std. Dev. & Min. & Max. \\
\hline I & 53,454 & 674.0295 & 531.3565 & 24.59 & 2230.43 \\
II & 77,686 & 1585.465 & 3376.23 & 98.36 & $17,804.34$ \\
III & 173,512 & 1837.073 & 1768.436 & 39.34 & $12,634.23$ \\
IV & 171,215 & 1811.388 & 1890.692 & 35.4 & 9782.6 \\
V & 244,502 & 1644.583 & 1598.51 & 29.34 & 7160.86 \\
VI & 326,788 & 2524.736 & 3864.269 & 185.86 & $23,478.26$ \\
VII & 281,264 & 2839.662 & 3837.713 & 49.18 & $38,152.17$ \\
VIII & 508,830 & 3096.331 & 2782.44 & 73.36 & $16,672.13$ \\
IX & 451,227 & 5077.108 & 7156.195 & 117.39 & $44,021.73$ \\
X & 415,770 & 8826.861 & 8631.293 & 108.19 & $55,271.73$ \\
\hline
\end{tabular}

Source: Own elaboration based on ENIGH 2014 data.

and a maximum of $38,152.17$, and an average of 2839.66 , those in decile VIII, with a minimum payment of 73.36 and a maximum of 16,672.13, and an average of 3096.33, those in decile IX, with a minimum of 117.39 and a maximum of $44,021.73$, and an average of 5077.10, and by households in decile X, with a minimum debt payment of 108.19 to a maximum of 55,271.73, and an average of 8826.86.

By knowing the behavior of the types of debt and their weight for each household, they concentrate to arrive at the total burden of debt payment in the households. Here it is important to mention that the observation of the data can give for a detailed analysis for each type of debt, arriving to conform a weight of one hundred percent, at least of the known debt payment, since there can be the omission of data in the surveys carried out and especially the accounting of payment for an informal debt that is not documented in the analyzed database.

In Table 10, for the year 2012, the total financial burden of debt payment per quarter, as a percentage of income $(C f t)$, and as a percentage of expenditure $(C f t$ ), in the households of Mexico in the year 2014, had the following conformation: decile I represent 103.78 percent of their average real income $(M i)$ and 51.04 percent of their average total expenditure $(M g)$, decile II, 78.56 percent of their $(\mathrm{Mi})$, and 60.66 percent of their $(M g)$, decile III, 102.21 percent of their $(\mathrm{Mi})$, and 88.47 percent of their $(M g)$, decile IV, 50.11 percent of their $(M i)$, and 48.82 percent of their $(M g)$, decile V, 39.11 percent of their $(M i)$, and 41.61 percent of their $(M g)$, decile VI, with 40.24 percent of their $(M i)$ and 43.39 percent of their $(M g)$, decile VII, with 34.53 percent of their $(M i)$ and 41.37 percent of their $(M g)$, decile VIII, with 34.30 percent of its $(M i)$, and 43.27 percent of its $(M g)$, decile IX, with 33.49 percent of its $(M i)$ and 44.13 percent of its $(M g)$, finally decile $\mathrm{X}$, with 32.14 percent of its average real income and 50.37 percent, of its average total expenditure.

In Figure 2, the situation that households in Mexico will face in 2014, about 
Table 10. The total financial burden of debt payment, by quarter, in Mexican households in 2014.

\begin{tabular}{cccccc}
\hline & MCft & Mi & Mg & Cft & Cft \\
\hline & $\begin{array}{c}\text { Average/financial } \\
\text { burden } \\
\text { A }+ \text { B + C }\end{array}$ & M/income & Average/expense & $\begin{array}{c}\text { in percent } \\
\text { of the income }\end{array}$ & $\begin{array}{c}\text { in percent } \\
\text { of the expenditure }\end{array}$ \\
\hline Decil & & real & Total & & \\
I & 4210.5855 & 4057.321 & 8249.1 & $\mathbf{1 0 3 . 7 8}$ & $\mathbf{5 1 . 0 4}$ \\
II & 6087.62 & 7748.94 & $10,035.53$ & $\mathbf{7 8 . 5 6}$ & $\mathbf{6 0 . 6 6}$ \\
III & $11,099.132$ & $10,858.7$ & $12,546.26$ & $\mathbf{1 0 2 . 2 1}$ & $\mathbf{8 8 . 4 7}$ \\
IV & 7146.606 & $14,261.18$ & $14,638.9$ & $\mathbf{5 0 . 1 1}$ & $\mathbf{4 8 . 8 2}$ \\
V & 6993.394 & $17,883.08$ & $16,806.54$ & $\mathbf{3 9 . 1 1}$ & $\mathbf{4 1 . 6 1}$ \\
VI & 8852.334 & $21,998.83$ & $20,403.52$ & $\mathbf{4 0 . 2 4}$ & $\mathbf{4 3 . 3 9}$ \\
VII & 9542.759 & $27,633.17$ & $23,068.89$ & $\mathbf{3 4 . 5 3}$ & $\mathbf{4 1 . 3 7}$ \\
VIII & $12,286.262$ & $35,819.39$ & $28,395.59$ & $\mathbf{3 4 . 3 0}$ & $\mathbf{4 3 . 2 7}$ \\
IX & $16,713.932$ & $49,902.04$ & $37,877.78$ & $\mathbf{3 3 . 4 9}$ & $\mathbf{4 4 . 1 3}$ \\
X & $36,077.771$ & $112,260.5$ & $70,752.29$ & $\mathbf{3 2 . 1 4}$ & $\mathbf{5 0 . 9 9}$ \\
Mean & $11,901.03955$ & $30,242.3151$ & $24,277.44$ & $\mathbf{5 4 . 8 5}$ & $\mathbf{5 1 . 3 7}$ \\
\hline
\end{tabular}

Source: Own elaboration based on ENIGH 2014 data.

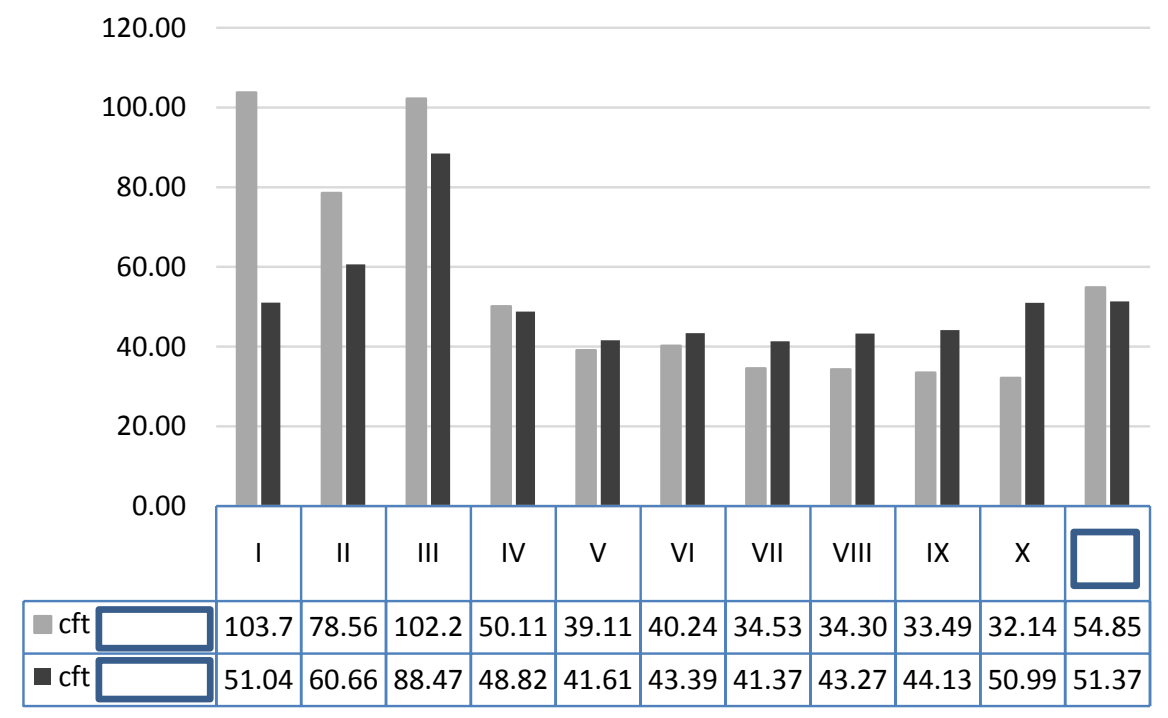

Figure 2. Illustration of the total financial burden about household income and expenditure in Mexico in 2014. Source: Own elaboration based on ENIGH 2014 data.

the total financial burden of debt by their real income and total expenditure, illustrates the conditions that each group of households with similar characteristics in the area is going through and highlights the very difficult situation of households in deciles I, II, III, and IV with the total absorption of expenditure over their income, This base can be one of many ways to plan for better household penetration. However, it highlights the difficult situation that debt is going 
through in our country since only households in decile $\mathrm{X}$ represent 32 percent of their income. The average of these figures is so disproportionate to the results by a group of households that they range from 54.85 percent in terms of the average total national burden about income to 51.37 percent in terms of total spending. An important comparison indicator is to set off the alarms about this issue.

In Table 11, the indebtedness index is in the proportion of 0 to 1 , values close to 1 represent a greater dependency, and those further away from 1 tend to be less dependent. In the results obtained, it would be irresponsible to consider the deciles corresponding to I, II, and III, decile. Since these households are in a situation of insolvency according to the result shown in the disposable income, their dependency index on the debt added to the dependency on the transfer of the expenditure to the subsidy is total. Based on this reflection, the households in decile IV have a debt dependency about their real income of 0.53 percent, those in decile $\mathrm{V}$ of 0.55 percent, those in decile VI of 0.53 percent, those in decile VII of 0.49 percent, those in decile VIII of 0.45 percent, those in decile IX of 0.42 percent, and those in decile $\mathrm{X}$ of 0.31 percent of debt dependency about their real income.

From the above, we can deduce that the origin of the debt is in the conception of consumption, and its base is the disposable income of the households, which would be the sum of their savings plus their income, which in the case of being weak, they use the debt to guarantee their needs, increasing their expectations. These results coincide with those found by López (2012) and Díaz et al. (2019), for Mexico, and Fuenzalida \& Ruiz Tagle (2009), for Chile, since they assert that the country faces different financial characteristics from those of countries experienced in monitoring financial risk, the greatest of which is the construction of a base per household to evaluate risks and implement measures to

Table 11. Household debt index in Mexico in 2014.

\begin{tabular}{ccccc}
\hline & MCft & Mi & Mg & Ie \\
\hline Decil & Mean/cargfin. & M/income & Mean/expense & Index of Indebtedness \\
I & 4210.5855 & 4057.321 & 8249.1 & \\
II & 6087.62 & 7748.94 & $10,035.53$ & 1.00 \\
III & $11,099.132$ & $10,858.7$ & $12,546.26$ & $\mathbf{0 . 5 1}$ \\
IV & 7146.606 & $14,261.18$ & $14,638.9$ & $\mathbf{0 . 1 3}$ \\
V & 6993.394 & $17,883.08$ & $16,806.54$ & $\mathbf{0 . 5 3}$ \\
VI & 8852.334 & $21,998.83$ & $20,403.52$ & $\mathbf{0 . 5 5}$ \\
VII & 9542.759 & $27,633.17$ & $23,068.89$ & $\mathbf{0 . 5 3}$ \\
VIII & $12,286.262$ & $35,819.39$ & $28,395.59$ & $\mathbf{0 . 4 9}$ \\
IX & $16,713.932$ & $49,902.04$ & $37,877.78$ & $\mathbf{0 . 4 5}$ \\
X & $36,077.771$ & $112,260.5$ & $70,752.29$ & $\mathbf{0 . 4 2}$ \\
Mean & $11,901.03955$ & $30,242.3151$ & $24,277.44$ & $\mathbf{0 . 3 1}$ \\
\hline
\end{tabular}

Source: Own elaboration based on ENIGH 2014 data. 
strengthen the economy per household.

\section{Conclusion}

In countries with characteristics such as those of Mexico, according to the analysis made in this research, it is likely that there will not be excellent financial planning at the macroeconomic level, even leading to the granting of Nobel prizes for their achievement, however having a nation subjected to conditions observed macroeconomically, will risk limiting its development, on the contrary, responsible debt management can be the lever of development towards the welfare of a nation. The correct financial planning of a household effectively falls on those who obtain their income to cover the needs according to their expectations, however, these can expand or decrease, if the parties involved: government system, management of financial societies in the country, ignore the situation that occurs in each household and this leads to the acceleration and dependence on debt for the satisfaction of their consumption and housing needs, which is added to the disproportionate interest rates, considerably increase their financial burden, which in many occasions slows down or leads to the bankruptcy of the economic development of the households in Mexico.

As future lines of research, it would be important to analyze the probability of indebtedness, given the characteristics and level of household income in Mexico.

\section{Conflicts of Interest}

The authors declare no conflicts of interest regarding the publication of this paper.

\section{References}

Comisión Nacional Bancaria y Valores (CNBV) (2015). Annual Report, pp. 1-203.

Cox, D. R. (1972). Regression Models and Life-Tables (with Discussion). Journal of the Royal Statistical Society, Series B: Methodological, 34, 187-220. https://doi.org/10.1111/j.2517-6161.1972.tb00899.x

Díaz Rodríguez, H. E., Sosa Castro, M., \& Cabello, R. A. (2019). Determinates del endeudamiento de los hogares en México: Un análisis con redes neuronales. Problemas del desarrollo. Revista Latinoamericana de Economía, 50, 115-140. https://doi.org/10.22201/iiec.20078951e.2019.199.67463

Fisher, I. (1930). The Theory of Interest, as Determined by Impatience to Spend Income and Opportunity. New York: The Macmillan Company.

Friedman, M. (1957). A Theory of the Consumption Function. Princeton, NJ: Princeton University Press. https://doi.org/10.1515/9780691188485

Fuenzalida, M., \& Ruiz Tagle (2009). Riesgo financiero de los hogares. Economía Chilena, $12,35-53$.

Hall, R. E. (1978). Stochastic Implications of the Life Cycle-Permanent Income Hypothesis: Theory and Evidence. Journal of Political Economy, 86, 971-987.

https://doi.org/10.1086/260724

Instituto nacional de estadística y geografía (INEGI) en México, encuesta nacional de ingreso y gasto en los hogares, 2014. 
Kaplan, E. L., \& Meier, P. (1958). Nonparametric Estimation from Incomplete Observations. Journal of the American Statistical Association, 53, 457-481.

https://doi.org/10.1080/01621459.1958.10501452

Keynes, J. M. (1992). Teoria general de la ocupacion, el interes y el dinero (2nd ed.) Buenos Aires: Fondo de Cultura Economica.

Laibson, D. I., \& Harris, C. (2001). Dynamic Choices of Hyperbolic Consumers. Econometrica, 69, 935-957. https://doi.org/10.1111/1468-0262.00225

López Bolaños, A. (2012). Crece el 64\% deuda en los hogares del país, revela la UNAM. Sol de Morelia.

Mankiw, G. (2007). Macroeconomía. Antoni Bosch Editor.

Modigliani, F. (1970). The Life-Cycle Hypothesis and Intercountry Differences in the Saving Ratio. In W. A. Eltis, M. F. G. Scott, \& J. N. Wolfe (Eds.), Introduction, Growth, and Trade: Essays in Honour of Sir Roy Harrod (pp. 197-225). Oxford: Oxford University Press.

National Council for Financial Inclusion (2017). 8vo Reporte Nacional de Inclusion Financiera, Comision Nacional Bancaria y de Valores. Mexico: CNBV. 